\title{
RELATIONSHIP BETWEEN ACR AND OTHER DETERMINANTS OF MICROALBUMINURIA IN T2DM PATIENTS
}

\section{AUTHORS}

Dijana J. Miric ${ }^{1}$, Bojana M Kisic ${ }^{1}$, Dragana Puhalo-Sladoje ${ }^{2}$, Bratislav M. Miric ${ }^{3}$, Dragisa Rasic ${ }^{4}$, Ilija M. Dragojevic ${ }^{1}$, Dragana Pavlovic ${ }^{2}$

${ }^{1}$ Institute of Biochemistry, Faculty of Medicine Pristina, Kosovska Mitrovica, Serbia

${ }^{2}$ Biochemical Laboratory, Faculty of Medicine, University of East Sarajevo, Foca, Bosnia and Herzegovina

${ }^{3}$ Department of Informatics, State University of Novi Pazar, Novi Pazar, Serbia

${ }^{4}$ Clinics for Internal Diseases, Faculty of Medicine Pristina, Kosovska Mitrovica, Serbia
CORRESPONDENT

Dijana J. Miric

Institute of Biochemistry,

Faculty of Medicine Pristina

(Kosovska Mitrovica)

Anri Dinan Street, bb

28220 Kosovska Mitrovica, Serbia

miric.dijana@gmail.com

\section{SUMMARY}

Introduction: The occurrence of microalbuminuria in type 2 diabetes mellitus (T2DM) patients is regarded as an early clinical sign of incipient kidney damage. Microalbuminuria is often evaluated as urinary albumin to urinary creatinine ratio (ACR).

Aim: To assess determinants of microalbuminuria in T2DM patients without prior diagnosis of nephropathy using ACR cut-off values.

Materials and Methods: ACR was measured in a total of 90 T2DM patients, during two months in three non-consecutive days, and routine biochemical analyses were performed, including glycated hemoglobin (HbA1c), serum uric acid (SUA), and atherogenic index of plasma (AIP). The cut-off values of ACR were $\leq 2.5 \mathrm{mg} / \mathrm{mmol}$ in males, and $\leq 3.5 \mathrm{mg} / \mathrm{mmol}$ in females. Duration of T2DM, history of hypertension, HbA1c, estimated glomerular filtration rate (eGFR), AIP, and SUA were investigated for association with microalbuminuria.

Results: According to ACR patients were considered as non-albuminuric $(n=57)$ and microalbuminuric $(n=33)$. Compared to non-albuminuric group, microalbuminuric group had increased urinary creatinine, urinary albumin, HbA1c, triglycerides and SUA, whilst decreased HDL-cholesterol levels. Although eGFR was generally reduced, the correlation between LogACR and eGFR was not significant $(p>0.05)$. However, the correlation between LogACR and LogHbA1c was significant. The multiple logistic regression analysis revealed HbA1c $(\mathrm{t}=3.42 ; \mathrm{p}=0.012)$ and SUA $(\mathrm{t}=2.44 ; \mathrm{p}=0.040)$ as independent predictors of microalbuminuria in T2DM patients.

Conclusion: At ACR cut-off values, concentrations of HbA1C and SUA were independent predictors of microalbuminuria in T2DM patients not yet diagnosed with nephropathy.

Keywords: Microalbuminuria, T2DM, ACR, Determinants

\section{SRPSKI}

\section{SAŽETAK}

Увод: Код пацијената са типом 2 шећерне болести (Т2ДМ) појава микроалбуминурије се сматра раним клничким знаком наступајућег обољења бубрега. Микроалбуминурија се најчешће одређује као однос албумина и креатинина у урину (АЦР).

Циљ: Циљ ове студије је да уоптребом преломних вредности АЦР-а истражи детерминанте микроалбуминурије код пацијената са Т2ДМ код којих дијагноза дијабетичне нефропатије још увек није постављена.

Материјал и методе: Код 90 пацијената са Т2ДМ је три пута у току два месеца одређиван АЦР, као и рутинске биохемијске анализе, укључујући ту концентрацију гликационог хемоглобина (HbA1c), мокраћне киселине (СУА), и атерогени индекс плазме (АИП). Преломне вредности за АЦР су биле $\leq 2.5 \mathrm{mg} / \mathrm{mmol}$ за мушкарце, и $\leq 3.5 \mathrm{mg} / \mathrm{mmol}$ за жене. Као предикторске варијабле за микроалбуминурију узети су: дужина трајања Т2ДМ, податак о хипертензији, НbА1с, брзина гломеруларне филтрације (eGFR), АИП и СУА.

Резултати: На основу преломних вредности АЦР-а 57 пацијената није имало микроалбуминурију, док је 33 имало мироалбуминурију. У поређењу са групом без микроалбуминурије, група са микроалбуминуријом је имала већу концентрацију креатинина у урину, албумина у урину, НbA1c, триглицерида и СУА, а нижу концентрацију ХДЛ-холестерола. Иако је генерално већи број испитаника имао ниже вредности eGFR, корелација између LogACR и eGFR није била 
статистички значајна ( $>$ > 0.05), док је коралација између LogACR и LogHbA1c била значајна. Мултипла логистичка регресиона анализа је показала да су HbA1c $(\mathrm{t}=3.42 ; \mathrm{p}=0.012)$ и SUA $(\mathrm{t}=2.44 ; \mathrm{p}=0.040)$ независни предиктори микроалбуминурије код пацијената са Т2ДМ.

Закључак: Код пацијената са Т2ДМ код којих дијагноза нефропатије још увек није постављена су концентрације НbА1с и SUA независни предиктори микроалбуминурије.

Кључне речи: Микроалбуминурија, Т2ДМ, АЦР, детерминанте

\section{INTRODUCTION}

Diabetic nephropathy (DN) is a relatively frequent microvascular complication of chronic hyperglycemia in type 2 diabetes mellitus (T2DM) patients, characterized by progressive fall of glomerular filtration rate (GFR), hypertension and persistent proteinuria, mainly albuminuria [1, 2]. In clinical practice, even a minimally increased urinary albumin excretion is regarded as an early sign of incipient kidney damage, with potential to progress to overt renal disease. Given that DN is highly prevalent in both developed and developing countries and is still rising among end-stage renal disease patients [3, 4], assessment of urinary albumin excretion rate and recognition of associated risk factors of diabetic kidney damage are of great importance.

Microalbuminuria is defined as urinary albumin excretion rate within the range of $20-300 \mathrm{mg}$ per day, found in two non-consecutive urine samples during three months period [2]. As urinary albumin excretion rate may be influenced by diurnal variations and other collection issues, urinary albumin to urinary creatinine concentration ratio (ACR) has been introduced for better accuracy [5 - 11]. On the other hand, the most clinicians prefer to assess kidney function as estimated GFR (eGFR), a mathematical approximation usually calulated by Modification of Diet in Renal Disease (MDRD) study group formula, which includes data regarding age, sex, ethnicity, and serum creatinine. However, serum creatinine levels can be unchanged untill even $50 \%$ of kidney function is lost, thus eGFR may not always reliably reflect the degree of kidney damage [7].

Microalbuminuria is also considered as a risk factor for progressive renal impairment. Evidences suggest that poor glycemic control, high blood pressure, obesity, and atherogenic dyslipidemia, are the most important risk factors for the development of DN $[1,11,12]$. These risk factors are highly prevalent in adult Serbian population [13, 14], where $8.2 \%$ population is currently diagnosed with diabetes, predominantly with T2DM [15]. Even with regular use of antidiabetic, anti-hypertensive and lipid-lowering drugs, DN would eventually develop in a number of T2DM patients. Given that determinants of microalbuminuria may help identifying risk factors for diabetic kidney disease, this study has investigated the relationship between ACR and several demographical, biochemical and clinical parameters in patients withT2DM.

\section{MATERIAL AND METHODS}

\section{Study Design and Participants}

Enrolled were total of 90 patients both sexes previously diagnosed with T2DM but with no diagnosis of DN, who attended University Health Center at Foca for diabetes control. Patients were on regular anti-diabetic medication for at least 2 years. Not included were diabetics with macroalbuminuria (urinary albumin excretion $\geq 300 \mathrm{mg} /$ day), as well as those previously diagnosed with DN, renal calculosis, recent stroke or myocardial infarction, and with known hepatic, autoimmune or malignant diseases. This study was conducted in accordance with the Declaration of Helsinki. Informed consent was provided from all participants included after careful explanation of the study goals. The institutional review board of Faculty of Medicine Foca has approved this study.

\section{Data Collection}

Data regarding age, duration of diabetes, medication, history of hypertension, smoking habits, and clinically confirmed complications were recorded from patients' files. Hypertension was defined as having systolic blood pressure $\geq 140 \mathrm{mmHg}$, or diastolic blood pressure $\geq 90 \mathrm{mmHg}$, or on antihypertensive medication. Body mass index (BMI) was calculated at the middle of the study as the ratio of body weight $(\mathrm{kg})$ and square body height $\left(\mathrm{m}^{2}\right)$, and considered normal if $\leq 24.9 \mathrm{~kg} / \mathrm{m}^{2}$.

\section{Biochemical Measurements}

For determination of $\mathrm{ACR}$, patients provided the first morning urine sample in sterile urine sample containers. Samples were provided during two months in three nonconsecutive days. Venous blood was collected on the occasion of urine testing, after an overnight fasting, and taken into tubes with or without anticoagulant. The average values of all three measurements were taken for statistical analyses.

Concentration of urinary albumin was determined on biochemical analyzer (Cobas Integra 400, Roche Diagnostics) by immunoturbidmetric end-point method using Tinaquant Albumin Gen.2 assay kit (Roche Diagnostics $\mathrm{GmbH}$, Mannheim, Germany). The results were expressed as milligrams albumin per liter urine $(\mathrm{mg} / \mathrm{L})$. Concentration of creatinine in samples was determined kinetically, according to the method of Jaffe. The ACR value was calculated for each patient as urinary albumin $(\mathrm{mg} / \mathrm{L})$ to urinary creatinine $(\mathrm{mmol} / \mathrm{L})$ ratio. The criterion for normal urinary albumin excretion was ACR $\leq 2.5 \mathrm{mg} / \mathrm{mmol}$ in males, and ACR $\leq 3.5$ $\mathrm{mg} / \mathrm{mmol}$ in females [9]. Estimated glomerular filtration rate (eGFR) was calculated according to MDRD formula [10].

The other biochemical parameters, including serum total proteins, albumin, triglycerides, total cholesterol, HDLcholesterol, and uric acid (SUA) were measured using standard protocols. Concentration of glycated hemoglobin A1C (HbA1c) was assessed from anticoagulated blood samples by turbidimetric inhibition immunoassay method. Atherogenic index of plasma (AIP) was calculated according to Dobiasova [16], as the logarithm of triglycerides to HDL-cholesterol ratio [Log (TG/HDL-cholesterol)].

\section{Statistical Analysis}

Statistical analysis was performed using STATISTICA 6.0 software package (StatSoft, Tulsa, OK, USA). Frequency 
distribution and homogeneity of variance was tested by Kolmogorv-Smirnov test. Data were presented either as arithmetic mean $\pm \mathrm{SD}$, geometric mean and $95 \%$ confidence interval of the mean, or frequencies $(\mathrm{n})$. Differences between groups were tested by Student's independent samples t-test or chi-square test, where appropriate. For comparisons, geometric means were back-transformed. The correlation analysis was accomplished by calculation of Spearman's rank coefficient. The relationship between possible determinants and ACR was investigated by performing binary logistic regression analysis and by means of general regression models. Statistically significant finding was considered if $\mathrm{p}<0.05$.

\section{RESULTS}

ACR values were measured in a total of 90 patients with T2DM without previous diagnosis of DN. All were Caucasians, 42 males and 48 females, aged $63.8 \pm 10.6$ years, with diabetes duration from 2 to 16 years. The majority of participants were overweight (BMl: $28.1 \pm 4.1 \mathrm{~kg} / \mathrm{m}^{2}$ ), with slightly reduced eGFR $\left(77.9 \pm 13.9 \mathrm{~mL} / \mathrm{min} / 1.73 \mathrm{~m}^{2}\right)$, and with average glycemic control of $\mathrm{HbA} 1 \mathrm{c}=74.9 \mathrm{mmol} / \mathrm{mol}(69.8-80.3 \mathrm{mmol}$ $/ \mathrm{mol})$. Complications were previously recorded in 35 patients (chi-square=4.011; $p=0.045$ ), as having one or more of the following: neuropathy $(n=27)$, retinopathy $(n=9)$, angiopathy $(n=8)$, and maculopathy $(n=5)$.

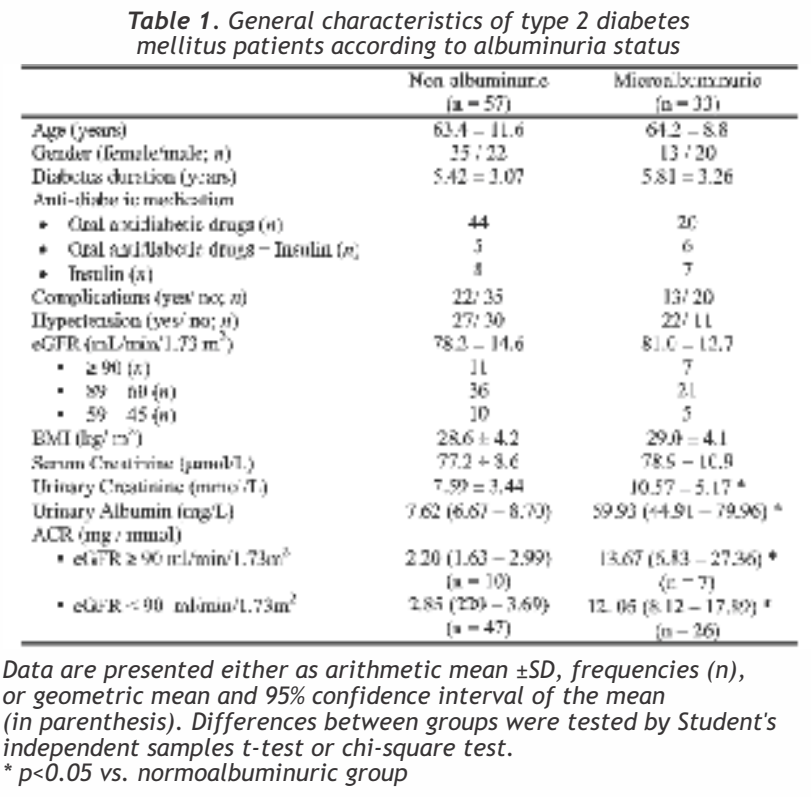

According to accepted criterion for ACR reference values [9], patients were assigned to non-albuminuric $(n=57)$ or microalbuminuric group $(n=33)$. Basic demographical, clinical and biochemical findings in these groups are presented in Table 1. As expected, concentrations of urinary albumin and ACR were significantly higher in microalbuminuric than in non-albuminuric group, irrespective of whether eGFR was within the normal range $\left(\geq 90 \mathrm{ml} / \mathrm{min} / 1.73 \mathrm{~m}^{2}\right)$ or decreased (Table 1). Urinary creatinine excretion was higher in microalbuminuric group, while serum creatinine levels and eGFR did not differ between groups (Table 1 ).

Indices of nutritional status and glycemic control are presented in Table 2. Compared to non-albuminuric group, patients with microalbuminuria had lower concentrations of HDL-cholesterol, and higher concentrations of SUA, triglyce- rides and blood HbA1c. Also, AIP was higher in microalbuminuric than in non-albuminuric group, but the difference did not reach statistical significance $(p=0.094)$.

Table 2. Nutritive status and glycemic control in patients with T2DM according to albuminuria status

\begin{tabular}{|c|c|c|}
\hline & $\begin{array}{c}\text { Non alburninumie } \\
(a=57)\end{array}$ & 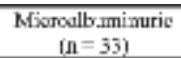 \\
\hline Totul pnoseins ( $g^{\prime} \mathrm{L}$; & $756 \pm 4.1$ & $7 \delta .7=5 . \AA$ \\
\hline Albumin $(\mathrm{N} / \mathrm{L})$ & $4.1+1.9$ & $43.8-2.7$ \\
\hline 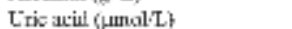 & $274 \pm 81$ & $328=60^{\circ}$ \\
\hline Total cholstesol (musl i L & $6(0)=\rfloor .45$ & $5,62=1,05$ \\
\hline Triglvcerides (maul L) & $2.21 \quad 0.66$ & 3. $\mathrm{F}_{\mathrm{f}}=1 . \mathrm{n} \mathrm{3}$ - \\
\hline IDL-ctolenteral (irmuli L) & L.49 $\quad 0.44$ & $1,28=0,33^{*}$ \\
\hline ATP [T.ng (ri glyeeridesHHII] & $0.187=0.210$ & $0.267=0.230$ \\
\hline HbAle faubslinul\} & $68.5(63.2-74.3)$ & $87.2177 .8-97.81=$ \\
\hline
\end{tabular}

Data are presented as arithmetic mean \pm SD, or geometric mean and $95 \%$ confidence interval of the mean (in parenthesis). Differences between groups were tested by Student's independent samples $t$-test. ${ }^{*} p<0.05$ vs. non-albuminuric group

The correlation analysis revealed no statistically significant relationship between eGFR and either ACR (rho $=-0.161 ; p>0.05)$, or urinary albumin concentration (rho=0.157; $p>0.05$ ), while LogACR was significantly correlated to LogHbA1c (Figure 1).

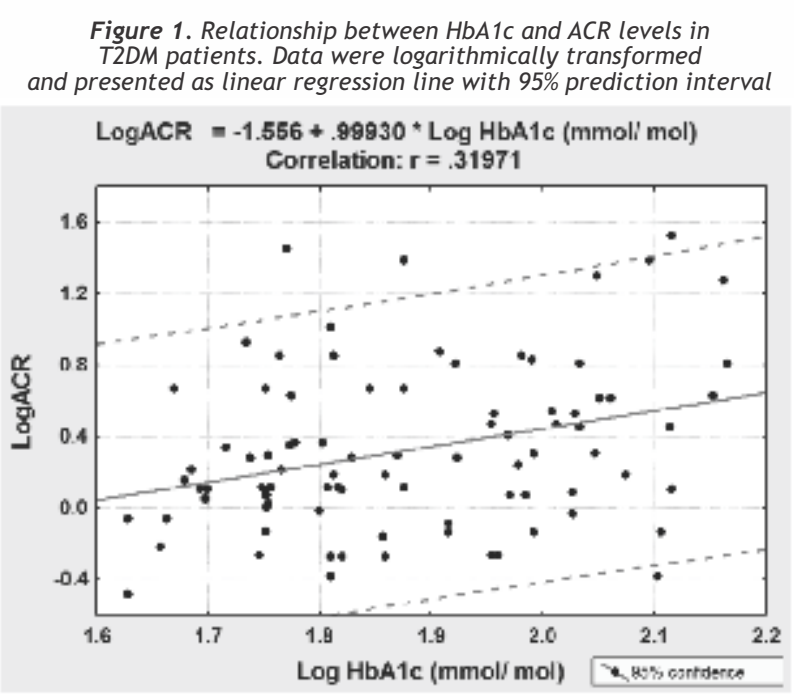

By performing logistic regression analysis we further investigated relationships between microalbuminuria (yes vs. no), defined according to accepted ACR cut-off values [9], and some possible risk factors for diabetic kidney injury. The duration of diabetes, eGFR, a history of hypertension (yes vs. no), AIP, SUA and blood HbA1c concentrations were considered as predictor variables.

Table 3. Multivariable logistic regression analysis for association between microalbuminuria and risk factors for incipient kidney damage in T2DM patients

\begin{tabular}{|c|c|c|c|c|}
\hline Ledepsadeat prodiotons & B & Sid. Drvor & p $\mathrm{VNu}$ re & OR $193 \% \mathrm{CD}$ \\
\hline 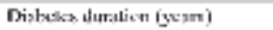 & -10.925 & n,0R4 & 0.754 & 1. $0746,83-1,159$ \\
\hline Hyxencosim (ye+ (x. m) & 11.6.646 & $11.53 \mathrm{~g}$ & 11.230 & 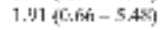 \\
\hline$\alpha_{i}=R\left(\mathrm{nll}_{i} \mathrm{~min}^{\prime} 1.53 \mathrm{~m}^{2}\right)$ & 11. .121 & n.1.19 & ก. 200 & 1.112 (1). 106$)$ \\
\hline AIP [Ling (thiglycerides/HIJ)] & 1.446 & $1.2 x \Omega$ & 10342 & $4.117\{0.31-4278\}$ \\
\hline Hhilc (mmeli ind) & fi.nits & 0.814 & n.sot & 1.ndution 1007 \\
\hline Senua uxit: *ial (umol Ll & 0.008 & 0.004 & 0.011 & $1.01\{1.00 \quad 1002$ \\
\hline Conş⿻二丨 $(\mathrm{M})$ & $-7,597$ & & 0,001 & \\
\hline
\end{tabular}

The multivariate logistic regression analysis revealed HbA1c $(t=3.49 ; p=0.001)$ and SUA $(t=2.38 ; p=0.020)$ as statistically significant independent predictors of microalbuminuria in T2DM patients (Table 3). 


\section{DISCUSSION}

In the current study, the occurrence of microalbuminuria was independently associated with both high blood $\mathrm{HbA1C}$ and SUA levels, confirming that diabetic kidney injury is principally due to chronically poor glycemic control $[1,4,5]$. Given that SUA is also considered as a biomarker of endothelial dysfunction [17], these results suggest involvement of hyperglycemia-associated endothelial dysfunction in the development of diabetic renal complications. However, ACR values were poorly correlated to eGFR, which is the most preferable clinical tool for assessment of kidney function.

Glycemic control is usually assessed by measuring HbA1c level, although many other proteins, such as serum albumin, more readily undergo glycation process. It has been shown that, compared to hemoglobin molecule, glucose binds to serum albumin with 10 times greater affinity, resulting that in chronic hyperglycemia up to $30 \%$ albumin molecules are at glycated form [18]. Indeed, concentration of glycated serum albumin highly corresponds to HbA1c levels in the absence of anemia [19]. Serum proteins are usually present in tissues, where can play important roles by maintaining cell viability, but can also induce serious tissue damage. Serum albumin, for example, if present at low concentrations, supports the survival of proximal epithelial tubular cells and macrophages [20]. However, at higher concentrations albumin can induce pro-inflammatory and profibrotic response, either acting as an inhibitor of podocyte insulin-dependent antiinflammatory angiotensin-converting enzyme-2, or by sensitizing tubular cells to potentially toxic compounds transported by albumin [21, 22]. Glycated albumin was shown to be even more nephrotoxic since it induces interstitial fibrosis at very low concentration [23]. In established microalbuminuria both glycated and unmodified albumin molecules are expected to be present in ultrafiltrate at supraphysiological levels. Since these molecules are nephrotoxic per se and are present at high levels in ultrafiltrate, they can further exaggerate tissue injury leading to overt kidney damage. Still, microalbuminuria may not always progress to macroalbuminuria but may regress, instead, [24], pointing that multiple factors can be implicated in the development and progression of diabetic kidney injury.

In previous studies SUA levels above the normal range were linked to vascular complications of T2DM [25, 26]. In the current study, SUA was independently associated with microalbuminuria. However, in the current study SUA concentrations were within the normal range in the most participants, although in microalbuminuric group tended to distribute mostly within the upper reference limits of the method. Recently, these high-normal values of SUA were suggested to predict the annual decline of eGFR and the development of chronic kidney disease among T2DM patients with relatively preserved kidney function [27]. Uric acid is a degradation product of purine catabolism, extensively formed in cells under hypoxic conditions. It is now accepted that beside of being a marker of cellular energy crisis, SUA can be both a mediator and a biomarker of generalized endothelial dysfunction, inflammation and vascular disease [17].

Although atherosclerosis and hypertension exacerbate cellular energy crisis, we observed only a weak association between microalbuminuria and the history of hypertension (Table 3, Figure 2). It has to be noted that data regarding hypertension were collected as qualitative, from medical records, and therefore must be cautiously interpreted. It was reported that microalbuminuria was associated with systolic rather than diastolic blood pressure or pulse pressure, representing an indicator of hemodynamic disturbances [11]. Hypertension is highly prevalent among Serbian population and in Republic of Srpska [14], which is the probable reason why the proportion of patients with history of hypertension was similar in both non-albuminuric and albuminuric groups in the study. Also, the most of hypertensive patients were treated with ACE inhibitors (data not presented), previously reported to postpone the onset of microalbuminuria in hypertensive T2DM patients [28]. ACE inhibitors were also demonstrated to restore megalin expression in proximal tubular cells, and normalize albumin tubular reabsorption, thereby reversing microalbuminuria in sterptozotocin diabetic rats [29].

Association between microalbuminuria and AIP, as a surrogate marker of atherogenic dyslipidemia [16], was also weak in our study. Atherogenic dyslipidemia, characterized by increased plasma triglycerides, decreased HDL-cholesterol and altered composition of LDL-cholesterol, is a wellknown risk factor for the development and progression of diabetic nephropathy [12, 30]. Recently, one meta-analysis study reported that AIP can predict the risk of T2DM in general population [31], and there was a significant association between AIP and microalbuminuria in non-diabetic patients with essential hypertension [32]. Also, ACR and HDL-cholesterol were poorly correlated (rho $=-0.139 ; p=0.189)$, and in accordance to one previous report [33].

The results of the current study indicate that major determinants of microalbuminuria in T2DM patients were increased blood $\mathrm{HbA} 1 \mathrm{C}$ and SUA levels. It has to be noted that we assessed microalbuminuria as ACR values. Still, recent studies suggest that reliability of ACR for assessment of kidney function can be sometimes questionable [7 - 9]. Namely, ACR may underestimate cases with slightly increased urinary albumin excretion and concomitantly increased urinary creatinine excretion, such as in male diabetics with greater muscle mass [31], and in diabetics with preserved renal compensatory mechanisms [7]. To corroborate, we observed that serum creatinine levels were within the normal range whilst urinary creatinine levels were higher in microalbuminuria (Table 1), suggesting that renal adaptive mechanisms were still operational in a number of patients with increased ACR. Also, there was a relatively weak correlation between ACR and eGFR, despite the fact that the majority of participants with microalbuminuria $(78.8 \%)$ were with mildly or moderately reduced eGFR. This is in accordance to some previous studies who found that approximately one third T2DM patients with mild and $14 \%$ with moderate renal impairment may have normal ACR values [34, 35], and that ACR levels do parallel eGFR mostly in macroalbuminuria [36].

To conclude, blood $\mathrm{HbA} 1 \mathrm{c}$ and serum UA levels were significant determinants of microalbuminuria, suggesting that a long-lasting hyperglycemia and endothelial dysfunction synergistically contribute to diabetic kidney complications in T2DM patients. Given that increased urinary albumin excretion rate can be considered not only as a marker but also as a mediator of kidney damage, and that the occurrence and the degree of albuminuria may not always parallel the reduction of kidney function, we suggest that the surveillance of kidney damage in T2DM should be based on both ACR and eGFR determinations.

\section{CONFLICT OF INETERST}

The authors declare no financial or other conflict of interest regarding this manuscript. 


\section{REFERENCES}

1. Toyama T, Furuichi K, Ninomiya T, Shimizu M, Hara A, Iwata Y, et al. The impacts of albuminuria and low eGFR on the risk of cardiovascular death, all-cause mortality, and renal events in diabetic patients: Meta-analysis. PLosOne 2013; 8(8): e71810. (https://doi.org/10.1371/journal.pone.0071810.g003)

2. Bakker AJ, Bierma-Ram A, Keidel H, Syperda H, Zijlstra A. (Micro)Albuminuria: antigen excess detection in the Roche modular analyzer. Clin Chem 2005; 51:1070 - 1071. (https://doi.org/10.1373/clinchem.2005.048215)

3. Djukanovic Lj, Aksic-Milicevic B, Antic M, Bakovic J, Varga Z, Gojakovic B, et al. Epidemiology of end-stage renal disease and hemodialysis treatment in Serbia at the turn of the millennium. Hemodial Int 2012; 16:517 - 525. (https://doi.org/10.1111/j.1542-4758.2012.00681.x)

4. Dragovic T. Microalbuminuria in diabetes: definition, identification techniques, and the significance of early recognition. Vojnosanit Pregl 2006; 63: 1027 - 1032. (https://doi.org/10.2298/vsp0612027d )

5. Sugawara A, Kawai K, Motohashi S, Saito K, Kodama S, Yachi Y, et al. HbA1c variability and the development of microalbuminuria in type 2 diabetes: Tsukuba Kawai Diabetes Registry 2. Diabetologia 2012; 55:2128 - 2131. (https://doi.org/10.1007/s00125-012-2572-7)

6. Levin, A., Stevens, P. E., Bilous, R. W., Coresh, J., De Francisco, A. L. M., De Jong, P. E., Griffith, K. E., Hemmelgarn, B. R., Iseki, K., Lamb, E. J., Levey, A. S., Riella, M. C., Shlipak, M. G., Wang, H., White, C. T., \& Winearls, C. G. (2013). Kidney disease: Improving global outcomes (KDIGO) CKD work group. KDIGO 2012 clinical practice guideline for the evaluation and management of chronic kidney disease. Kidney International Supplements, 3(1); 1-150. (https://doi.org/10.1038/kisup.2012.73)

7. Donadio C, Lucchesi A, Ardini M, Giordani R. Cystatin C. b2-microglobulin, and retinol-binding protein as indicators of glomerular filtration rate: comparison with plasma creatinine. J Pharm Biomed Anal 2001; 24:835 - 842. (https: //doi.org/10.1016/s0731-7085(00)00550-1)

8. Johns KW, Robinson CE, Wilson IM, Billington EO, Bondy GP, Tildesley HD. Does albumin:creatinine ratio lack clinical utility in predicting microalbuminuria? BC Med J 2006; 48:399 - 403. (https://www.researchgate.net/publication/289016727)

9. Lemley KV, Abdullah I, Myers BD, Meyer TW, Blouch K, Smith WE, et al. Evolution of incipient nephropathy in type 2 diabetes mellitus. Kidney Int 2000; 58:1228 - 1237. (https://doi.org/10.1046/j.1523-1755.2000.00223.x)

10. Levey AS, Bosch JP, Lewis JB, Greene T, Rogers N, Roth D. A more accurate method to estimate glomerular filtration rate from serum creatinine: a new prediction equation. Modification of Diet in Renal Disease Study Group. Ann Int Med 1999; 130:461 - 470. (https://doi.org/10.7326/0003-4819-130-6-199903160-00002)

11. Basi S, Mimran A, Fesler P, Lewis JB. Microalbuminuria in Type 2 diabetes and hypertension. Diabet Care $2008 ; 31$ (S2): S194 - S201. (https://doi.org/10.2337/dc08-s249)

12. Lee IT, Wang CY, Huang CN, Fu CC, Sheu WHH. High triglyceride-to-HDL cholesterol ratio associated with albuminuria in type 2 diabetic subjects. J Diabet Complicat 2013; 27: 243 - 247. (https://doi.org/10.1016/j.jdiacomp.2012.11.004)

13. Grujic V, Dragnic N, Radic I, Harhajl S, Susnjevic S. Overweight and obesity among adults in Serbia: Results from the national health survey. Eating Weight Disord 2010; 15: e34 - e42. (https://www.researchgate.net/publication/44695692)

14. Grujuc V, Dragnic N, Kvrgic S, Susnjevic S, Grujic J, Travar S. Epidemiology of hypertension in Serbia: Results of national survey. J Epidemiol 2012; 22: 261 - 266. (https://doi.org/10.2188/JEA.JE20110077)

15. Serbian Diabetes Registry. Incidence and mortality of diabetes in Serbia 2012. Report N0. 7. Institute of Public Health of Serbia “Dr Milan Jovanovic Batut”. Belgrade, 2012. ISBN 978-86-7358-040-1.

16. Dobiasova $M$, Frohlich J. The plasma parameter $\log (T G / H D L-C)$ as an atherogenic index: correlation with lipoprotein particle size and esterification rate in apoB-lipoprotein-depleted plasma (FERHDL). Clin Biochem 2001; 34:583 - 588. (https: //doi.org/10.1016/S0009-9120(01)00263-6)

17. Kanellis J, Kang DH. Uric acid as a mediator of endothelial dysfunction, inflammation, and vascular disease. Seminn Nephrol 2005; 25:39 - 42. (https://doi.org/10.1016/j.semnephrol.2004.09.007)

18. Fanali G, di Masi A, Trezza V, Marino M, Fasano M, Ascenzi P. Human serum albumin: from bench to bedside. Mol Aspects Med 2012; 33:209 - 290. (https://doi.org/10.1016/j.mam.2011.12.002)

19. Nathan DN, McGee P, Steffes MW, Machin JM, DCCT/EDIC Research Group. Relationship of glycated albumin to blood glucose and HbA1C values and to retinopathy, nephropathy, and cardiovascular outcomes in the DCCT/ EDIC Study. Diabetes 2014; 63: 282 - 290. (https://doi.org/10.2337/db13-0782)

20. Iglesias J, Levine JS. Albuminuria and renal injury - beware of proteins bearing gifts. Nephrol Dial Transplant 2001; 16:215 218. (https://doi.org/10.1093/ndt/16.2.215)

21. Marquez E, Riera M, Pascual J, Soler MJ. Albumin inhibits the insulin-mediated ACE2 increase in cultured podocytes. Am J Physiol Renal Physiol 2014; 306:F1327- F1334. (https://doi.org/ 10.1152/ajprenal.00594.2013)

22. van Timmeren MM, Gross ML, Hanke W, Klok PA, van Goor H, Stegeman CA, et al. Oleic acid loading does not add to the nephrotoxic effect of albumin in an amphibian and chronic rat model of kidney injury. Nephrol Dial Transplant 2008; 23:3814 - 3823. (https://doi.org/10.1093/ndt/gfn417)

23. Gross ML, Piecha G, Bierhaus A, Hanke W, Henle T, Schirmacher P, et al. Glycated and carbamylated albumin are more "nephrotoxic" than unmodified albumin in the amphibian kidney. Am J Physiol Renal Physiol 2011; 301:F476 - F485. (https://doi.org/10.1152/ajprenal.00342.2010) 
24. Tabaei BP, Al-Kassab AS, Ilag LL, Zawacki CM, Herma WH. Does microalbuminuria predict diabetic nephropathy? Diab Care 2001; 24:1560 - 1566. (https://doi.org/ 10.2337/diacare.24.9.1560)

25. Chuengsamaran S, Rattanamongkolgul S, Jirawatnotai S. Association between serum uric acid level and microalbuminuria to chronic vascular complications in Thai patients with type 2 diabetes. J Diab Complic 2014; 28:124 - 129. (https://doi.org/ 10.1016/j.jdiacomp.2013.12.002)

26. Fukui M, Tanaka M, Shiraishi E, Harusato I, Hosoda H, Asano M, et al. Serum uric acid is associated with microalbuminuria and subclinical atherosclerosis in men with type 2 diabetes mellitus. Metabolism 2008; 57:625 - 629. (https://doi.org/ 10.1016/j.metabol.2007.12.005)

27. Kim WJ, Kim SS, Bae MJ, Yi YS, Jeon YK, Kim BH, et al. High-normal serum uric acid predicts the development of chronic kidney disease in patients with type 2 diabetes mellitus and preserved kidney function. J Diab Complic 2014; $28: 130$ - 134. (https://www.researchgate.net/publication/259142107)

28. Amann B, Tinzmann R, Angelkort B. ACE inhibitors improve diabetic nephropathy through suppression of renal MCP-1. Diab Care 2003; 26:2421 - 2425. (https://doi.org/10.2337/diacare.26.8.2421)

29. Tojo A, Onozato ML, Kirahara H, Sakai T, Goto A, Fujita T. Angiotensin II blockade restores albumin reabsorption in the proximal tubules of diabetic rats. Hypertens Res 2003; 26: 413 - 419. (https://doi.org/10.1291/hypres.26.413)

30. Zhu XW, Deng FY, Lei SF. Meta-analysis of Atherogenic Index of Plasma and other lipid parameters in relation to risk of type 2 diabetes mellitus. Prim Care Diab 2015; 9:60 - 67. (https://doi.org/10.1016/j.pcd.2014.03.007)

31. Mattix HJ, Hsu CY, Shaykevich S, Curhan G. Use of albumin/creatinine ratio to detect microalbuminuria: implications of sex and race. J Am Soc Nephrol 2002; 13: 1034 - 1039. (https://www.researchgate.net/publication/11452710)

32. Moura RSSS, Vasconcelos DF, Frietas E, Moura FJD, Rosa TT, Veiga JPR. Cystatin C, CRP, Log TG/HDLc and metabolic syndrome are associated with microalbuminuria in hypertension. Arq Bras Cardiol 2014; $102: 54$ - 59. (https: / /doi.org/10.5935/abc.20130210)

33. Tseng CH. Differential dyslipidemia associated with albuminuria in type 2 diabetic patients in Taiwan. Clin Biochem 2009; 42:1019 - 1024. (https://doi.org/10.1016/j.clinbiochem.2009.03.013)

34. Maclsaac RJ, Tsalamandris C, Panagiotopoulos S, Smith TJ, McNeil KJ, Jerumes H. Nonalbuminuric renal insufficiency in type 2 diabetes. Diab Care 2004; 27: 195 - 200. (https://doi.org/10.2337/diacare.27.1.195)

35. Amin AP, Whaley-Connell AT, Li S, Cheng SC, McCullough PA, Kosiborod MN, on behalf of KEEP investigators. The synergistic relationship between estimated GFR and microalbuminuria in predicting long-term progression to ESRD or death in patients with diabetes: results from the Kidney Early Evaluation Program (KEEP). Am J Kidney Dis 2013; 61 : S12 - S23. (https://doi.org/10.1053/j.ajkd.2013.01.005)

36. Chida, S., Fujita, Y., Ogawa, A. et al. Levels of albuminuria and risk of developing macroalbuminuria in type 2 diabetes: historical cohort study. Sci Rep 2016: 6, 26380. (https://doi.org/10.1038/srep26380) 